\title{
Influence of Environmental Knowledge on Affect, Nature Affiliation and Pro-Environmental Behaviors among Tourists
}

\author{
Min-Seong Kim, Jinwon Kim * (1) and Brijesh Thapa \\ Department of Tourism, Recreation and Sport Management, University of Florida, Gainesville, FL 32611-8208, \\ USA; minseong@ufl.edu (M.-S.K.); bthapa@hhp.ufl.edu (B.T.) \\ * Correspondence: jinwonkim@ufl.edu; Tel.: +1-352-294-1625
}

Received: 7 August 2018; Accepted: 27 August 2018; Published: 31 August 2018

\begin{abstract}
Jeju Island is a popular destination in South Korea that is dependent on nature-based tourism. The annual increase in the influx of visitors has created major environmental impacts due to overuse and commercial expansion. With projected growth in arrivals and the development of tourism infrastructure, the island will experience perpetual challenges for sustainable management of natural resources. However, the role of visitors will be central via a commitment to practice pro-environmental behaviors to protect the island from further degradation. This study was grounded in the cognition-affection-attitude-behavior model to examine the predictive validity of tourists' environmental knowledge, environmental affect, and nature affiliation on pro-environmental behavior. The data comprised responses from 304 domestic visitors who had visited Jeju Island. The empirical findings indicate that environmental affect was significantly impacted by two dimensions of environmental knowledge (i.e., subjective and objective). Additionally, nature affiliation was positively impacted by environmental affect, while pro-environmental behavior was significantly influenced by both environmental affect and nature affiliation. Overall, these findings provide theoretical and practical implications for sustainable tourism at a nature-based destination. The findings can be utilized for implementation of intervention programs and visitor management at Jeju Island.
\end{abstract}

Keywords: environmental knowledge; environmental affect; nature affiliation; pro-environmental behavior; Jeju Island; South Korea

\section{Introduction}

Nature-based destinations face challenges to sustain the ecological resources due to their popularity and high demand among visitors [1]. The influx has led to negative impacts in various destinations largely because of visitors' depreciative behaviors towards wildlife, resource, and environmental setting [2-4]. Hence, monitoring and managing visitor behaviors have become major management issues to mitigate impacts and promote responsible behaviors [3,4].

Visitors' pro-environmental behaviors have been extensively examined in recent decades to gain insight into protection of destinations' natural resources, and avert negative impacts $[5,6]$. Research has generally adopted the attitude-behavior model to anticipate visitors' pro-environmental behaviors [6,7], while few studies have investigated whether behaviors are related to attitudes, cognition, and emotions towards nature $[8,9]$. This latter aspect requires additional research with regards to the examination of the antecedents of tourists' pro-environmental behaviors based on individual cognition and emotions toward the environment, since individual attributes may be relatively stable compared to destination-based constructs to predict their behaviors $[8,10]$. 
Furthermore, Cheng and $\mathrm{Wu}$ [8] adopted the cognition-affection-attitude-behavior model [11] and suggested that tourists' environmental knowledge can lead to concern and respect for the environment at a destination. This could arouse tourists' functional and affective attachment to the place visited, which in turn, might influence the exhibition of pro-environmental behaviors [12]. The use of such a conceptual framework that integrates cognition, affection, attitude, and behavior demonstrates the joint function of environment-related variables and their interactions. In addition, studies based on this model have considered environmental knowledge as a critical determinant of tourists' emotions, attitudes, and behavior, while others have examined the distinct influences of environmental knowledge (i.e., subjective and objective) on the consequences [8,13].

Moreover, environmental knowledge is a significant cognitive factor that leads tourists to engage in responsible behaviors and reduce their negative environmental impacts [8]. Environmental knowledge may strengthen a tourist's cognition of environmental conservation since it can enhance their ability to act responsibly [14]. A tourist develops environmental knowledge through concern for and understanding of both nature and environmental issues from educational programs provided at the destination [15-17]. Likewise, those with an increased level of environmental knowledge are generally likely to demonstrate more concern, empathy, and appreciation towards nature at the destination [18,19]. Therefore, an emphasis to improve tourists' environmental knowledge can result in more positive emotional responses to nature.

Environmental affect, which refers to an individual's enduring feeling toward the natural environment, especially emotional responses to degradation [20], is considered a critical driver for participation in environmentally responsible behaviors. According to Lee and Jan [7], the connection between environmental knowledge and response to nature can promote tourists' pro-environmental behaviors. Hence, if tourists gain internal environmental affect towards nature via environmental knowledge, they attribute a symbolic belongingness or meaning to the destination [21]. As a result, tourists will exhibit pro-environmental behaviors toward the destination's natural resources. Additionally, affiliation with nature is a component of attitudes toward nature as the meaning reflects various contexts, that includes social, cultural, and natural [22]. Thus, tourists that have an increased level of affiliation with nature are most likely to behave responsibly at the destination.

Based on these lines of inquiry, this study seeks to further expand the academic literature with an examination of the interrelationship between the dimensions of environmental knowledge, environmental affect, affiliation with nature, and pro-environmental behaviors among tourists at a nature-based destination. First, this study examined the impacts of two distinct aspects of environmental knowledge on environmental affect (i.e., the influence of knowledge on emotion may differ from subjective and objective aspects). Second, the interrelationships among environmental affect, affiliation with nature, and pro-environmental behavior (i.e., focus on individual attributes instead of destination ones) were identified. Third, the mediated roles of environmental affect and nature affiliation between the two types of environmental knowledge and pro-environmental behavior (i.e., expand the cognition-affection-attitude-behavior model for nature-based destination) were tested.

This research focused on Jeju Island, South Korea, which is considered as the most popular nature-based destination in the country, and attracts approximately 14.7 million visitors annually ( $20 \%$ are international and $80 \%$ domestic) [23]. The number of domestic visitors continues to increase as evident from 12.2 million in 2016 to 13.5 million in 2017. This visitor influx along with tourism infrastructure development has created challenges for sustainable management of natural resources (e.g., a substantial amount of trash and overuse of natural resources) [23]. While the role of tourism is central to the island's economy, the optimal balance between economic development and environmental conservation is an ongoing issue that is acknowledged by stakeholders, and has led to calls by residents and the local Destination Management Organization for additional protections by the government. Recent initiatives in the application of sustainable tourism have been conducted with appropriate environmental management, and promotion of responsible behaviors among visitors [24]. Nevertheless, a new international airport is planned to be built to attract more tourists, and future 
impacts are likely to be sustained given the constant major flow of tourists. Thus, the role of visitors will be central via a commitment to practice pro-environmental behaviors to protect the island from further degradation.

This research provides an avenue for a baseline assessment of current domestic visitors with regards to their level of environmental knowledge, affect, nature affiliation and pro-environmental behaviors. The findings can be utilized for intervention programs and visitor management at Jeju Island. Overall, tourists are a major stakeholder in the sustainable tourism development process as their perspectives on the visited destination can assist in policy formulation and management initiatives [17]. Accordingly, this paper is outlined as follow: Literature review (theoretical background, constructs, and research hypothesis development); methods (research site, data collection, and sample, and measures); results (sample characteristics, two-step analyses and structural modeling for testing hypotheses); discussion and implications, and conclusion.

\section{Literature Review}

\subsection{Theoretical Background}

A conceptual framework that involves the cognitive, affective, and attitudinal components has been employed to understand and predict behavior $[8,11,25]$. As a tourist processes information at a nature-based destination, in particular, a cognitive component exists that, in turn, forms beliefs that determine whether the consequences of his/her behavior will be negative or positive to the destination's natural resources. If the outcome of the behavior is assumed to be positive, then the tourist will have a positive emotional response to his/her behavior at the destination [25]. Attitude comprises affective components and is reflected in behavior [25], while cognition is a driver of affection that leads to attitudes and behavior [25-27]. Following this conceptual underpinning, this study utilizes environmental knowledge as cognition, environmental affect as affection, and pro-environmental behavior as an outcome of affiliation with nature (i.e., attitude toward nature) (see Figure 1).

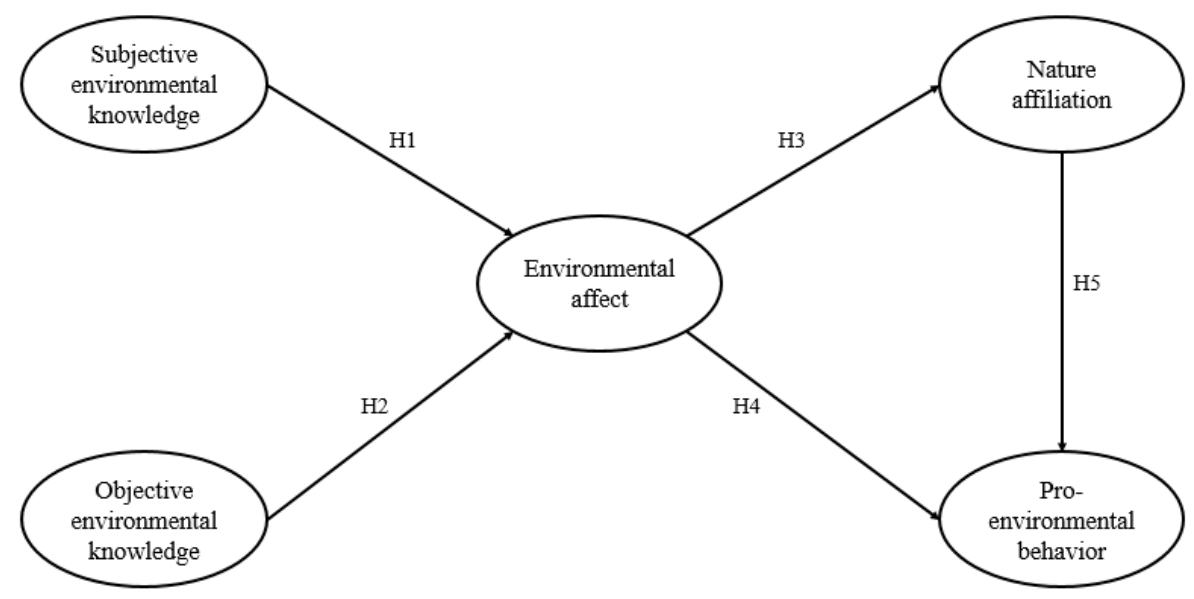

Figure 1. Research model.

\subsection{Environmental Knowledge}

Environmental knowledge is conceptualized as an understanding of environmental issues and consists of an individual's familiarity that is related to environmental influence, appreciation, and collective responsibility [28]. According to D'Souza, Taghian, and Lamb [29], environmental knowledge can be divided into two forms: (1) Knowledge with regards to an individual's influence on nature, and (2) knowledge with respect to the ways to reduce an individual's impact. However, even when individuals have a high level of environmental knowledge, their behaviors towards nature 
may not change [30]. In addition, environmental knowledge leads to a high level of awareness, which, in turn, promotes favorable attitudes toward nature [29].

Several scholars have empirically investigated the influence of environmental knowledge on other variables [28,31]. Although previous research has considered environmental knowledge to be uni-dimensional, it needs to be segmented into two constructs based on the amount of "real" (objective) and "perceived" (subjective) knowledge with regards to environmental problems and solutions [32]. Essentially, subjective knowledge is based on individuals' feeling of knowing about the environment while objective knowledge is about actual knowledge. Specifically, differences exist between objective and subjective aspects, i.e., when an individual does not accurately recognize their level of understanding of environmental knowledge [32]. This is because individuals learn varying levels and aspects of knowledge about environmental issues and solutions (e.g., someone may focus more on issues than solutions, and vice versa). Basically, subjective and objective environmental knowledge can each manifest differently, and have distinct influences on an individual's decision-making process [33]. More specifically, subjective knowledge is a combination of 'self-confidence' and environmental knowledge, so that its influence may differ from that of objective knowledge (i.e., the level of real knowledge itself) [32]. Hence, this study conceptualizes environmental knowledge as two aspects (i.e., subjective and objective) to analyze tourists' knowledge with regards to nature, environmental issues, and solutions.

\subsection{Environmental Affect}

Environmental affect is conceptualized as an enduring feeling towards nature, particularly emotional reactions to environmental issues and problems [20]. If an individual has greater emotional empathy toward nature, they are more likely to behave responsibly, and as a result, their affinity for nature may increase [34]. Prior studies have also suggested that pro-environmental behavior is motivated by environment-specific emotions, such as environmental affect, moral emotion, and ecological fear $[20,35,36]$. In addition, those who have a high level of specific emotions tend to be more engaged in outdoor recreation activities, and limit their negative impacts on animals and plants during travel [20]. Interestingly, several researchers [37,38] have suggested that an individual who has lower levels of knowledge about nature can exhibit a closer emotional relationship. This is because environmental affect is related to the level at which individuals embrace nature within their cognitive representation [34,37]. However, strong environmental affect cannot significantly lead to pro-environmental behaviors of individuals due to the absence of a mediator between emotion and behavior [20].

\subsection{Nature Affiliation and Pro-Environmental Behavior}

People in the industrialized world can feel detached from nature due to urbanization as efficiency improvements, habitat loss, and reduced workforce in natural resource-based industries (e.g., forestry, agriculture, and fisheries) are evident [39]. Therefore, an increasing population has lost the opportunity to experience nature, and do not recognize the significance of environmental problems and issues globally [40]. This lack of exposure may exacerbate the destruction of nature and negatively influence human beings' understanding, attitudes, and behaviors [39]. Hence, studies in the fields of environmental education, human geography, conservation biology, and environmental psychology have focused on the conceptualization of nature and its antecedents and consequences of being disconnected [41]. An individual's affiliation with nature is described as a cognitive, affective, and/or physical relationship with nature [42] and can be a significant driver of pro-environmental behavior [41,43]. Individuals have an intrinsic need to be affiliated with nature $[44,45]$. More specifically, individuals need to feel affiliated not only with other people as part of a certain group but also with nature [41].

In general, tourists' pro-environmental behavior includes contributions to environmental conservation and/or preservation efforts, decrease negative impacts on the natural resources, 
and act responsibly during participation in recreational activities [6]. More specifically, tourists' pro-environmental behavior at a destination includes preserving its natural resources, respecting the local culture, and decreasing their interference with the natural environment [46]. Tourists who do not aggressively practice pro-environmental behaviors may damage the ecosystems via depreciative activities such as, feeding wildlife, overturning rocks, and disturbing vegetation and creatures [2].

\subsection{Research Hypothesis Development}

The influence of knowledge on a tourist's behavior poses explanatory challenges [47]. While knowledge alone cannot motivate individuals to adopt new behaviors, a lack thereof may be a barrier to change behavior $[48,49]$. Hence, prior studies have focused on environmental affect's mediating role in the association between tourists' attitudes and environmental knowledge [47]. In addition, an increased level of knowledge is most likely to engender greater empathy towards nature [8]. Individuals who know more about nature and their impacts have an innate affect that optimizes biophilic tendencies [44,50]. However, the different dimensions of environmental knowledge need to be distinguished based on their subjectivity and objectivity due to varying influences on decision-making [13]. Hence, the following hypotheses are conceptually formulated:

Hypotheses 1 (H1). Subjective environmental knowledge is positively associated with environmental affect.

Hypotheses 2 (H2). Objective environmental knowledge is positively associated with environmental affect.

When an individual experiences a positive emotion in a particular context, it facilitates "the broadening of thought-action repertoires and the self [41] (p. 178)", which promotes "open-minded, curious and exploratory thoughts and actions [41] (p. 179)" and a wide approach towards the world and other people $[41,51,52]$. Tourists who have such an experience display a greater engagement in positive and alternative behaviors at a destination [53]. Empirically, several studies have indicated that environmental affect anticipates altruistic or pro-social behaviors, which are designed to serve the public good [54,55]. Tourists' pro-environmental behaviors have been characterized to ensure limited impacts to nature at the visited destination [2]. Thus, a tourist who experiences a positive emotion is likely to pay more attention to global nature issues, which could broaden environmental thoughts and behaviors [8]. Accordingly, the hypotheses are framed as follows:

Hypotheses 3 (H3). Environmental affect is positively associated with affiliation with nature.

Hypotheses 4 (H4). Environmental affect is positively associated with pro-environmental behavior.

Greater affiliation with nature is related to tourists' favorable attitudes toward the environment, concern about harmful impacts of behaviors, and greater tendency to behave in a pro-environmental manner [41,43]. Specifically, tourists can internalize their personal values with regards to the importance of nature; thus, it may become a part of their personal values, and subsequently, a concern to protect may emerge [41]. Behaviorally, tourists who have a higher nature affiliation may be more engaged in environmentally responsible behaviors, and spend more time in outdoor recreation activities [41]. In addition, they are more likely to exhibit a higher desire to preserve and/or maintain the natural environment given their level of affiliation [56]. Accordingly, this hypothesis is proposed:

Hypotheses 5 (H5). Nature affiliation is positively associated with pro-environmental behavior.

\section{Methods}

\subsection{Research Site}

Jeju island is one hour away by airplane from any major Korean city. It is popular among domestic and international tourists due to its own unique culture, dialect, and history that differs from the mainland. In addition to its cultural resources, Jeju has significant natural assets, such as Mt. Halla (highest peak in the country), blue oceans, large caverns, orange trees, and scenic places to visit. 
Based on its cultural and environmental aspects, the island has been inscribed as a Biosphere Reserve in 2002, Natural World Heritage Site in 2007, and Global Geopark in 2010 [57]. In addition, it has also been listed on the New Seven Wonders of Nature since 2011 [58] (see Figure 2).

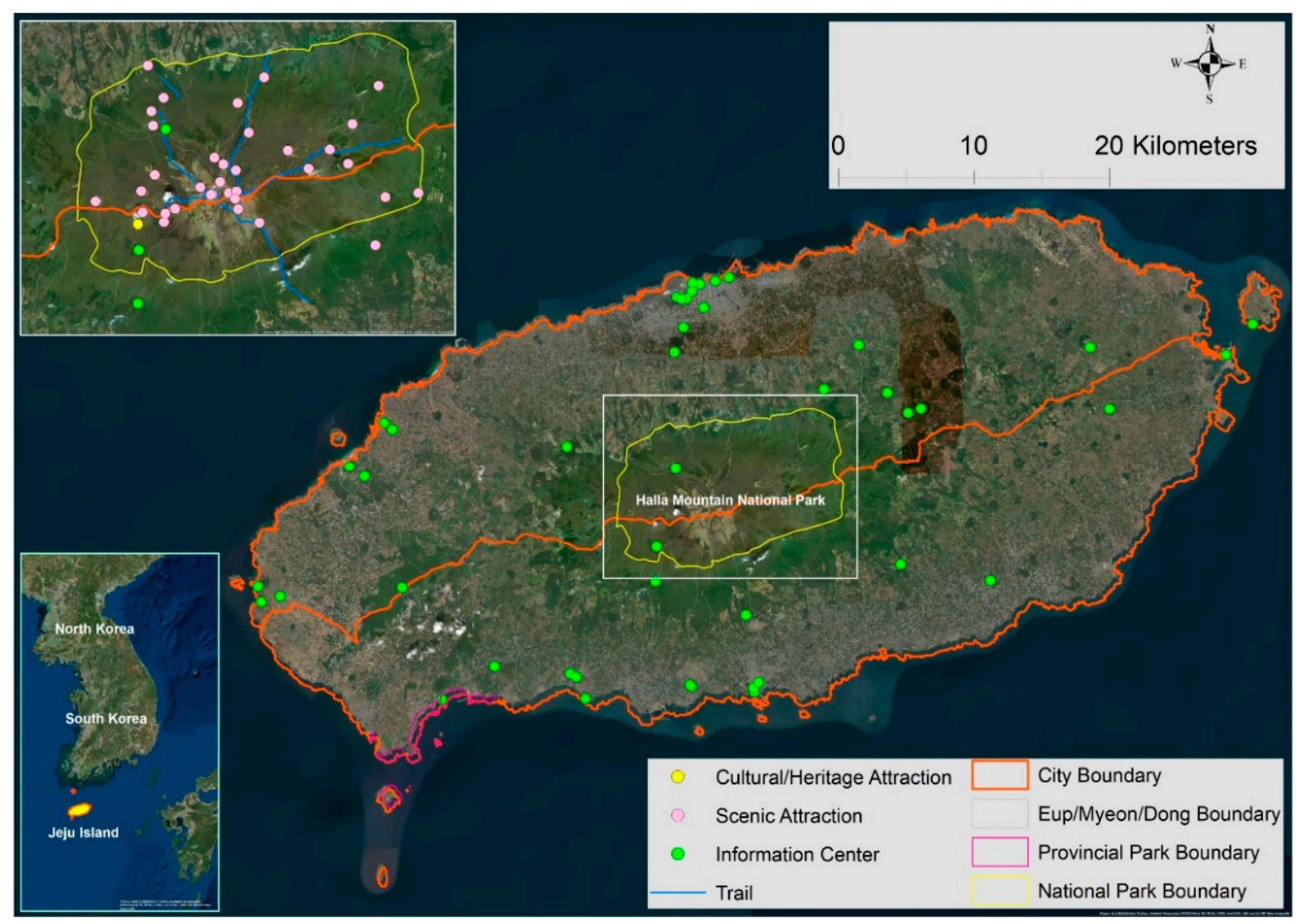

Figure 2. Study site.

\subsection{Data Collection and Sample}

A cross-sectional survey of domestic visitors was conducted. First, a pilot test among current visitors $(N=25)$ was done, and subsequent minor modifications were undertaken. Second, during the sampling phase, the lead author delivered a hard copies of the survey to fifteen travel agencies that had agreed to assist with data collection. This study used a convenience sampling approach due to the assistance and cooperation provided. More specifically, tour guides affiliated with the travel agencies distributed the questionnaire to visitors to the island. In total, 400 questionnaires were distributed during the month of August 2015. The number of usable returned responses was 304 (24 incomplete questionnaires and 72 refusals) which yielded a $76 \%$ response rate.

The incomplete surveys were removed from the usable sample to avoid bias. To measure the potential nonresponse bias, this study employed a time trend extrapolation test [59]. This test assumes the late participants whose responses were received following the second mailing, should be considered as non-respondents [60]. If an independent t-test reveals any significant differences $(p<0.05)$ in the antecedents of a dependent variable between the respondents and late respondents, the dependent variable estimates could be potentially biased [61]. The findings of this test indicated lack of statistically significant differences between the two groups (respondents vs. late respondents). Thus, respondents included in this study appear to be free from indications of non-response bias. Finally, the usable sample size was considered adequate. Essentially, for a research model with five latent variables and 18 observed variables (i.e., desired statistical power level: 0.8 ; anticipated effect size: 0.3 ; probability level: 0.05), the recommended minimum sample size is 150 [62]. 


\subsection{Measures}

The selected measures of environmental knowledge, environmental affect, nature affiliation, and pro-environmental behavior were conceptually developed and empirically tested in prior studies with acceptable reliability scores and validity. Except for measures related to objective environmental knowledge, all were operationalized via a seven-point Likert scale format where 1 = strongly disagree to 7 = strongly agree. Subjective environmental knowledge was operationalized as perceived knowledge of environmental issues and solutions [63] and was measured with four items [28]. Objective environmental knowledge was measured with four items [64]. For the multivariate analysis, only correct responses were summed to generate a score for the seven aspects of objective environmental knowledge (i.e., 1 point per correct answer from 0 to 4 in total). Environmental affect was defined as a tourist's level of emotional response to an environmental problem and was measured with four items $[65,66]$. Nature affiliation was operationalized and measured with five items [56,67], while pro-environmental behaviors encompassed four items [68].

\section{Results}

\subsection{Sample Characteristics}

Participants were mostly males and comprised of $54.9 \%$, while females represented $45.1 \%$. About $42.1 \%$ were less than 29 years, $25.7 \%$ in their $40 \mathrm{~s}$, and $23.4 \%$ in their $30 \mathrm{~s}$. With respect to education, $40.5 \%$ of participants held a four-year university degree, followed by high school diplomas (35.2\%), two-year college degrees (12.8\%), and postgraduate degrees (8.6\%). In addition, $22.0 \%$ were office workers, followed by students $(21.7 \%)$, technical workers (19.1\%), professionals $(13.8 \%)$, and service workers (10.9\%). The annual household income varied as $34.2 \%$ reported an income of $\$ 36,001-\$ 48,000,33.2 \%$ below $\$ 36,000$, and $13.8 \%$ noted $\$ 60,001-\$ 72,000$ (see Table 1).

Table 1. Respondents' Profile $(N=304)$.

\begin{tabular}{|c|c|c|c|}
\hline Demographic Variables & & Frequency & Percent $(\%)$ \\
\hline \multirow{2}{*}{ Gender } & Female & 137 & 45.1 \\
\hline & Male & 167 & 54.9 \\
\hline \multirow{4}{*}{ Age } & Below 29 & 128 & 42.1 \\
\hline & $30-39$ & 71 & 23.4 \\
\hline & $40-49$ & 78 & 25.7 \\
\hline & Over 50 & 26 & 8.6 \\
\hline \multirow{4}{*}{ Education } & High school & 107 & 35.2 \\
\hline & College & 39 & 12.8 \\
\hline & University & 123 & 40.5 \\
\hline & $\begin{array}{l}\text { Graduate } \\
\text { school }\end{array}$ & 27 & 8.9 \\
\hline \multirow{7}{*}{ Occupation } & Students & 66 & 21.7 \\
\hline & Office workers & 67 & 22.0 \\
\hline & Professionals & 42 & 13.8 \\
\hline & Service & 33 & 10.9 \\
\hline & $\begin{array}{l}\text { Technical } \\
\text { workers }\end{array}$ & 58 & 19.1 \\
\hline & Housewives & 23 & 7.6 \\
\hline & Miscellaneous & 15 & 4.9 \\
\hline \multirow{5}{*}{ Annual household income } & Below $\$ 36,000$ & 101 & 33.2 \\
\hline & $\$ 36,001-\$ 48,000$ & 104 & 34.2 \\
\hline & $\$ 48,001-\$ 60,000$ & 27 & 8.9 \\
\hline & $\$ 60,001-\$ 72,000$ & 42 & 13.8 \\
\hline & Over $\$ 72,000$ & 30 & 9.9 \\
\hline
\end{tabular}




\subsection{Two-Step Analyses}

All measures, except for the objective environmental knowledge construct were checked for validity and reliability. The Cronbach's alpha coefficients illustrated from 0.774 (i.e., pro-environmental behavior) to 0.924 (i.e., environmental affect), and those that exceeded 0.70 were considered acceptable [69]. Subsequently, via AMOS version 20.0 (IBMSPSS, Chicago, IL, USA), a confirmatory factor analysis (CFA) was assessed to determine validity [70]. Three items that registered below 0.50 of standardized factor loadings were removed from the analyses (i.e., correlation analysis, structural equation modeling) to maintain recommended levels for discriminant and convergent validity.

The CFA results illustrate good fit indices as follows: $\chi^{2}=200.162$, d.f. $=81\left(\chi^{2} /\right.$ d.f. $\left.=2.471\right)$, $p$-value $<0.001$, the Root Mean Square Error of Approximation (RMSEA) $=0.070$, Normed Fit Index $(\mathrm{NFI})=0.931$, Comparative Fit Index $(\mathrm{CFI})=0.957$, Tucker-Lewis Index $(\mathrm{TLI})=0.945$, Incremental Fit Index (IFI) = 0.958 [71]. The Goodness-of-Fit Index (GFI), Adjusted Goodness-of-Fit Index (AGFI), and Root Mean Square Residual Index (RMR) were not considered because these indices are easily influenced by the sample size and model characteristics (i.e., tend to be attenuated with a larger number of indicators and factors and smaller sample sizes-see Bone, Sharma, and Shimp) [72]. All standardized factor loadings of each construct were over $0.50(p<0.01)$, which demonstrated convergent validity (see Table 2) [71]. Discriminant validity was checked by comparing proportions of average variance extracted (AVE) in each construct with squares of coefficients that represents their correlations [73]. Although pro-environmental behavior's AVE value (0.476) was less than 0.50 as suggested by Fornell and Larcker [73], the construct was significantly discriminated from other constructs since its AVE was larger than each squared correlation $\left(0.006 \leq \Phi^{2} \leq 0.294\right)$. As shown in Table 3, the AVE values were also over each squared correlation estimate to ensure discriminant validity [74].

Table 2. Results of confirmatory factor analysis (CFA) for the measurement model.

\begin{tabular}{|c|c|c|}
\hline Constructs and Items & $\begin{array}{l}\text { Standardized } \\
\text { Factor Loading }\end{array}$ & $t$-Value \\
\hline \multicolumn{3}{|l|}{ Subjective environmental knowledge $(\alpha=0.876)$} \\
\hline I am very knowledgeable about environmental issues. & 0.750 & Fixed \\
\hline I understand the environmental phrases and symbols noted on product packages. & 0.914 & 16.030 \\
\hline I know that I buy products that are environmentally safe. & 0.856 & 15.185 \\
\hline I know more about recycling than an average person. & - & - \\
\hline \multicolumn{3}{|l|}{ Environmental affect $(\alpha=0.924)$} \\
\hline It frightens me to think that much of the food I eat is contaminated with pesticides during this trip. & 0.854 & Fixed \\
\hline $\begin{array}{l}\text { It genuinely infuriates me to think that the government doesn't do more to help control pollution at } \\
\text { this destination. }\end{array}$ & 0.874 & 19.958 \\
\hline $\begin{array}{l}\text { I become incensed when I think about the harm being done to this destination's plants and animals } \\
\text { by pollution. }\end{array}$ & 0.899 & 20.995 \\
\hline I get frustrated and angry when I think of the ways the tourism industry causes pollution. & 0.847 & 18.904 \\
\hline \multicolumn{3}{|l|}{ Nature affiliation $(\alpha=0.866)$} \\
\hline I feel attached to nature during this trip. & 0.934 & Fixed \\
\hline I can relate with nature during this trip. & 0.934 & 22.581 \\
\hline I feel united with nature during this trip. & - & - \\
\hline I feel close to nature during this trip. & 0.670 & 13.953 \\
\hline I feel like a friend of nature during this trip. & - & - \\
\hline \multicolumn{3}{|l|}{ Pro-environmental behavior $(\alpha=0.774)$} \\
\hline I accept the control policy not to enter the wetland. & 0.757 & Fixed \\
\hline I help to maintain the local environmental quality. & 0.696 & 10.636 \\
\hline I report any environmental destruction or pollution to the park manager and/or administration. & 0.608 & 9.428 \\
\hline I try not to disrupt the fauna and flora during my travel. & 0.690 & 10.570 \\
\hline \multicolumn{3}{|c|}{ Objective environmental knowledge $^{1}$} \\
\hline \multicolumn{3}{|c|}{$\begin{array}{l}\chi^{2}=200.162, \text { d.f. }=81\left(\chi^{2} / \text { d.f. }=2.471\right), p \text {-value }<0.001, \text { RMSEA }=0.070, \text { NFI }=0.931, \text { CFI }=0.957, \text { TLI }=0.945, \\
\text { IFI = 0.958. } 1 \text { Objective environmental knowledge construct comprised four items (i.e., answers italicized): } \\
\text { "(1) Soil pollution is generally due to (A) sparse rains; (B) improper farming methods; (C) poisonous metals; } \\
\text { (D) over-fertilization; (E) poor crop rotation. (2) Ecology is best described as the study of (A) the relationship } \\
\text { between man and the environment; (B) the relationship between organisms and the environment; (C) pollution and its } \\
\text { control; (D) the environment; (E) recycling of products. (3) All but one of the following decomposes in ocean water } \\
\text { (A) sewage; (B) garbage; (C) tin cans; (D) plastic bags; (E) chemical fertilizer. (4) Practically all of the lead in the } \\
\text { atmosphere is caused by (A) cars; (B) industrial plants; (C) airplanes; (D) burning refuse; (E) cigarettes.". }\end{array}$} \\
\hline
\end{tabular}


Table 3. Mean, standard deviation (SD), construct intercorrelations $(\Phi)$, Composite Construct Reliability (CCR), Average Variance Extracted (AVE).

\begin{tabular}{|c|c|c|c|c|c|}
\hline Construct & 1 & 2 & 3 & 4 & 5 \\
\hline 1. Subjective environmental knowledge & 1 & & & & \\
\hline 2. Objective environmental knowledge & $\begin{array}{l}0.129^{* *} \\
(0.016)\end{array}$ & 1 & & & \\
\hline 3. Environmental affect & $\begin{array}{l}0.712 \text { ** } \\
(0.507)\end{array}$ & $\begin{array}{l}0.179 * * \\
(0.032)\end{array}$ & 1 & & \\
\hline 4. Nature affiliation & $\begin{array}{l}0.247^{* *} \\
(0.061)\end{array}$ & $\begin{array}{c}0.056 \\
(0.003)\end{array}$ & $\begin{array}{l}0.299 * * \\
(0.089)\end{array}$ & 1 & \\
\hline 5. Pro-environmental behavior & $\begin{array}{l}0.169 * * \\
(0.029)\end{array}$ & $\begin{array}{c}0.077 \\
(0.006)\end{array}$ & $\begin{array}{l}0.261^{* *} \\
(0.068)\end{array}$ & $\begin{array}{l}0.542^{* *} \\
(0.294)\end{array}$ & 1 \\
\hline Mean & 5.640 & 1.345 & 5.668 & 5.778 & 5.388 \\
\hline SD & 1.127 & 1.035 & 1.067 & 1.200 & 0.983 \\
\hline CCR & 0.880 & - & 0.925 & 0.889 & 0.783 \\
\hline AVE & 0.710 & - & 0.755 & 0.731 & 0.476 \\
\hline
\end{tabular}

Finally, a common method bias was conducted with Harman's one-factor test [75]. More specifically, if $\chi^{2}$ and d.f. of a single-factor model were significantly better than those of a multidimensional model (i.e., the proposed research model), a common method bias (CMB) likely existed (i.e., single latent variable accounts for all constructs) [76]. However, the values of the one-factor model's $\chi^{2}$ and d.f. were 2810.200 and d.f. $=91$, respectively (the five-dimensional research model: $\chi^{2}=200.162$ and d.f. $=81$ ). The $\chi^{2}$ and d.f. values of the single factor model were significantly worse which suggested $\mathrm{CMB}$ might not be a serious concern.

\subsection{Structural Equation Modelling and Hypothesis Testing}

The proposed relationships were empirically tested based on a covariance matrix. The overall model fit indices suggested the data fit well: $\chi^{2}=209.320$, d.f. $=85\left(\chi^{2} /\right.$ d.f. $\left.=2.463\right), p$-value $<0.001$, RMSEA $=0.069, \mathrm{NFI}=0.928, \mathrm{CFI}=0.956, \mathrm{TLI}=0.945, \mathrm{IFI}=0.956$. The maximum likelihood $(\mathrm{ML})$ estimates of the research model's parameters are indicated in Table 4 and Figure 3.

Table 4. Results of structural equation modeling for hypothesis testing.

\begin{tabular}{lcc}
\hline \multicolumn{1}{c}{ Path } & $\begin{array}{c}\text { Standardized } \\
\text { Estimates }\end{array}$ & $t$-Value \\
\hline Subjective environmental knowledge $\rightarrow$ Environmental affect & $0.786^{* *}$ & 12.278 \\
Objective environmental knowledge $\rightarrow$ Environmental affect & $0.096^{*}$ & 2.344 \\
Environmental affect $\rightarrow$ Nature affiliation & $0.314^{* *}$ & 5.230 \\
Environmental affect $\rightarrow$ Pro-environmental behavior & $0.501^{* *}$ & 7.449 \\
Nature affiliation $\rightarrow$ Pro-environmental behavior & $0.207^{* *}$ & 3.367 \\
\hline Endogenous variables & $\mathrm{SMC}\left(R^{2}\right)$ & \\
\hline Environmental affect & 0.647 \\
Nature affiliation & 0.099 \\
Pro-environmental behavior & 0.360 \\
$\chi^{2}=209.320$, d.f. $=85\left(\chi^{2} /\right.$ d.f. $\left.=2.463\right), p<0.001, \mathrm{NFI}=0.928, \mathrm{IFI}=0.956, \mathrm{TLI}=0.945, \mathrm{CFI}=0.956 . \mathrm{RMSEA}=0.069$,
\end{tabular}




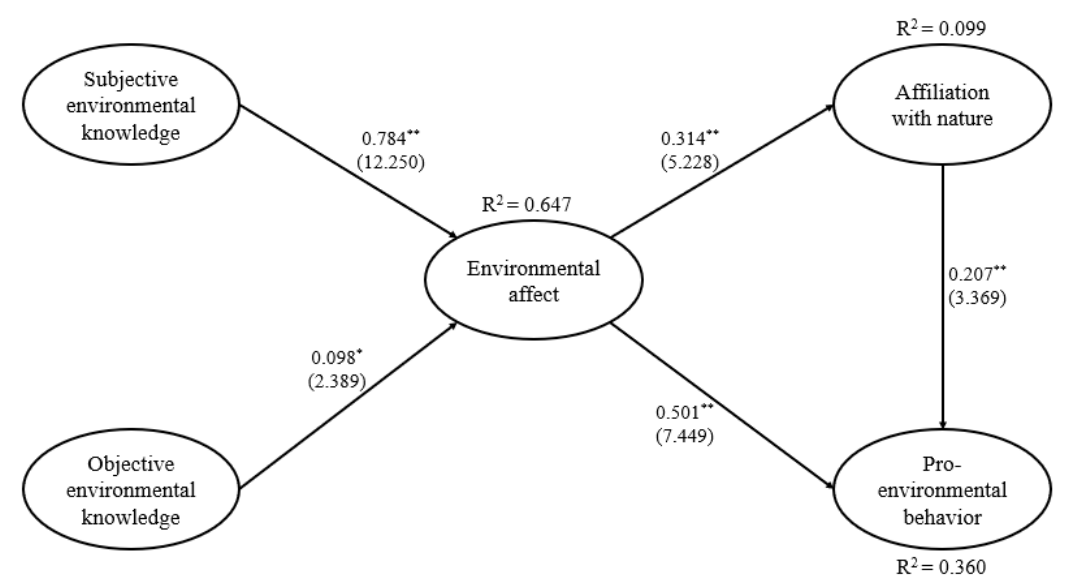

Figure 3. Estimates of structural equation modeling (SEM). Dotted line: non-significant path, solid line: significant path, standardized coefficient ( $t$-value), ${ }^{* *} p$-value $<0.01,{ }^{*} p$-value $<0.05$.

The results showed that environmental affect was significantly influenced by subjective environmental knowledge $(\beta=0.786, t$-value $=12.278)$ and objective environmental knowledge ( $\beta=0.096$, $t$-value $=2.344$ ). Therefore, H1 (at $p<0.01$ level) and H2 (at $p<0.05$ level) were supported. Similarly, environmental affect significantly influenced nature affiliation $(\beta=0.314, t$-value $=5.230)$ and pro-environmental behavior $(\beta=0.501, t$-value $=7.449$ ). Hence, $\mathrm{H} 3$ (at $p<0.01$ level) and H4 (at $p<0.01$ level) were supported. Finally, nature affiliation significantly influenced pro-environmental behavior $(\beta=0.207, t$-value $=3.367)$, hence H5 was supported (at $p<0.01$ level).

The roles of environmental affect and nature affiliation as mediators between environmental knowledge and behaviors were examined via Bootstrapping method and the Aroian version of the Sobel test [77]. In comparison with the traditional single-variable mediation approach, this combined analysis was more suitable [78] as this test addressed the level of significance of the independent variable's indirect influence via a mediator [77]. Tourists' environmental affect significantly mediated the impact of subjective environmental knowledge on nature affiliation (subjective environmental knowledge $\rightarrow$ environmental affect $\rightarrow$ nature affiliation; $0.247, p<0.01 ; 95 \%$ bootstrap confidence interval $[\mathrm{CI}]=0.157 \mathrm{LL}$ (Lower Level) $\mathrm{CI}=0.335 \mathrm{UL}$ (Upper Level); $\mathrm{Z}=2.239, p<0.05$ ). Additionally, environmental affect significantly mediated the influence of the environmental knowledge dimensions on pro-environmental behavior (subjective environmental knowledge $\rightarrow$ environmental affect $\rightarrow$ pro-environmental behavior; $0.445, p<0.01 ; 95 \%$ bootstrap CI $=0.344 \mathrm{LL} \mathrm{CI}=0.526 \mathrm{UL} ; \mathrm{Z}=4.046$, $p<0.01$ and objective environmental knowledge $\rightarrow$ environmental affect $\rightarrow$ pro-environmental behavior; $0.055, p<0.05 ; 95 \%$ bootstrap CI $=0.009 \mathrm{LL} \mathrm{CI}=0.109 \mathrm{UL} ; \mathrm{Z}=1.967, p<0.05$ ) (see Table 5).

Table 5. Results of the mediation test.

\begin{tabular}{|c|c|c|c|c|c|}
\hline Path & $\begin{array}{l}\text { Indirect } \\
\text { Effect }\end{array}$ & $\begin{array}{l}\text { LL CIs } \\
(95 \%)\end{array}$ & $\begin{array}{l}\text { UL CIs } \\
(95 \%)\end{array}$ & Z-Value & $\begin{array}{l}\text { Mediating } \\
\text { Role }\end{array}$ \\
\hline $\begin{array}{l}\text { Subjective environmental knowledge } \rightarrow \\
\text { Environmental affect } \rightarrow \text { Nature affiliation }\end{array}$ & $0.247^{* *}$ & 0.157 & 0.335 & $2.239 * *$ & Full mediator \\
\hline $\begin{array}{l}\text { Objective environmental knowledge } \rightarrow \\
\text { Environmental affect } \rightarrow \text { Nature affiliation }\end{array}$ & 0.030 * & 0.006 & 0.062 & 1.528 & Not significant \\
\hline $\begin{array}{l}\text { Subjective environmental knowledge } \rightarrow \\
\text { Environmental affect } \rightarrow \text { Pro-environmental behavior }\end{array}$ & $0.445^{* *}$ & 0.344 & 0.526 & $4.046^{* *}$ & Full mediator \\
\hline $\begin{array}{l}\text { Objective environmental knowledge } \rightarrow \\
\text { Environmental affect } \rightarrow \text { Pro-environmental behavior }\end{array}$ & 0.055 * & 0.009 & 0.109 & $1.967 *$ & Full mediator \\
\hline $\begin{array}{l}\text { Environmental affect } \rightarrow \text { Nature affiliation } \rightarrow \\
\text { Pro-environmental behavior }\end{array}$ & $0.065^{* *}$ & 0.026 & 0.118 & 1.852 & Not significant \\
\hline
\end{tabular}

** $p$-value $<0.01, * p$-value $<0.05$. 


\section{Discussion and Implications}

This research investigated the influences of two dimensions of environmental knowledge (i.e., subjective and objective) and environmental affect on affiliation with nature and proenvironmental behavior among domestic tourists at Jeju Island. The results revealed a positive significant relationship in which higher levels of subjective and objective environmental knowledge resulted in increased environmental affect. Basically, tourists with high levels of environmental knowledge were more concerned about the negative environmental impacts at the destination. This finding was consistent with Wu, Yeh, and Huan [79], who identified that tourists with an increased level of level of environmental knowledge tend to be more concerned about nature. Interestingly, the influence of subjective environmental knowledge on environmental affect was much stronger than that of objective environmental knowledge. This was also consistent with prior research as subjective knowledge was a stronger driver of green consumption behavior [32,80].

The results provide several contributions to the academic literature. First, a conceptual model with two dimensions of environmental knowledge (i.e., subjective and objective) in a nature-based tourism context was formulated and empirically tested. A tourist's environmental knowledge serves as the capability to recognize concepts, symbols, and behavioral patterns associated with environmental protection and conservation at a nature-based destination [81]. Thus, prior research on nature-based tourism revealed a direct causal relationship between a tourist's environmental knowledge and his or her environmentally responsible behavior at a destination $[8,19,81]$. However, tourism studies have considered environmental knowledge as uni-dimensional and investigated its impacts on destination-related constructs and pro-environmental behavior $[8,13]$. Importantly, knowledge relevant to green consumption (e.g., nature-based tourism packages) should be categorized into two distinct dimensions (i.e., subjective and objective knowledge) because of their differences [33]. For example, House et al. [80] identified that an increased level of subjective knowledge was significantly and positively associated with green behaviors, while objective knowledge was not. Consistent with this finding, subjective environmental knowledge was identified as a stronger driver of environmental affect than objective knowledge in this study. Thus, subjective environmental knowledge could be positively associated with a tourist's confidence in his or her environmental knowledge, and with stronger emotional responses to nature.

Second, with expansion on prior research, this study proposed that environmental affect and affiliation with nature were core mediators between environmental knowledge and behaviors. An individual's emotional connection with nature is dependent on a prior understanding of the natural environment and associated issues [82]. Within the nature-based tourism context, a tourist experiences the natural environment at his or her destination, which fosters environmental concern and a connection with nature [41]. Nature-based tourism facilitates connectedness to nature, and likely develops responsible behavior among tourists which, in turn, leads to a greater commitment to environmental protection [83]. This research was conducted to further explore the cognition-affection-attitude-behavior model that predicts tourists' pro-environmental behavior. More specifically, affiliation with nature developed through environmental affect expands and deepens a tourist's awareness that he or she is part of nature (i.e., a far larger living system), instead of merely a destination, which enables to transform their values, intentions, and behavior.

From a practical perspective, continuous education programs with regard to the importance of environmental knowledge should be reinforced to develop tourists' environmental affect. Tourists' knowledge of nature at a destination can be enhanced with activities and training of tour guides and destination management organizations (DMOs) representatives based on an emphasis on the topics of environmental protection, conservation and sustainable development [84]. Subsequently, these attendees could offer tours and services oriented towards visitor education and enhancement of their appreciation for and awareness of nature [34]. Hence, tourists can be educated with respect to subjective environmental knowledge, and be aware of the issues and could likely enhance site-specific environmental knowledge (i.e., objective environmental knowledge) [85]. In addition, a well-informed 
campaign could introduce tourists to environmentally responsible tourism at their destination. Thus, via participation in tours and services, tourists could gain and develop environmental knowledge about their destination, thereby enhancing their environmental affect.

A tourist's belief that nature leads to a higher quality of life influences his or her emotional bond with nature. In fact, emotional response to nature has a significant, positive impact on his or her commitment to participation in nature-based tours, and engage in pro-environmental behavior at a destination. This could suggest that a high level of emotional response to environmental problems could increase a tourist's intention to exhibit behaviors that support the protection of the environment and connect him or her to nature. Environmental consequences usually result in stronger emotional attachment to nature than environmental knowledge [86]. In addition, environmental affect can provide a new perspective with regards to the linkage between intentions and behaviors toward nature at their visited destinations.

DMOs may need to focus on fostering environmental affect among tourists, which could broaden attention and encourage awareness of and attentiveness to nature. Also, they should provide tourists with printed and online materials with regard to the destination's environmental issues and efforts to resolve problems. Futhermore, DMOs could also install signboards that emphasize the importance of nature and its relationship towards the enhancement of community quality of life. After such exposure to these signals, tourists might likely feel connected, and modify their behaviors at the visited destination. Basically, a nature-based experience can improve tourists' responsible actions and behaviors [41]. Thus, DMOs may need to design experiences for play, entertainment, and recreation to assist tourists to discover the destinations' invaluable natural resources. Overall, this study could assist DMOs to learn, adapt, and implement programs to boost environmental knowledge, and encourage pro-environmental behaviors at their sites.

This study has limitations that need to be considered. First, the empirically tested hypotheses need to be replicated with international tourists to consider all segments at nature-based destinations. Second, since other potential factors could influence the environmental sustainability of tourism, future research should consider additional variables that include tourists' beliefs and emotional states. Third, the data collection might have had a social desirability effect, as tourists completed the surveys in the presence of tour guides and other tourists.

\section{Conclusions}

This study addressed the influence of tourists' environmental knowledge on environmentally responsible behaviors based on the influence of select mediating variables at Jeju Island. Since environmental knowledge alone may not motivate individuals to behave responsibly, this model focuses on the role of emotional responses to and attitudes toward nature to determine environmental knowledge and behaviors. The results provide DMOs of nature-based destinations with several ways to use tourists' environmental knowledge to enhance attachment to nature. The development of an affiliation to nature may be one way to stimulate pro-environmentalism. Lastly, lack of a statistically significant relationship between tourist groups were identified, and research needs to further examine for differences via a multi-group analysis along with other antecedents of pro-environmental behaviors.

Author Contributions: All authors conceived and designed the study. M.-S.K. collected and analyzed data, and wrote Sections 1-4, and Section 6. J.K. wrote Section 5 and revised other sections. B.T. revised all sections.

Funding: This research received no external funding.

Acknowledgments: We would like to express our gratitude of three reviewers for their constructive comments and suggestions.

Conflicts of Interest: The authors declare no conflict of interest. 


\section{References}

1. Thapa, B.; Lee, J. Visitor experience in Kafue National Park, Zambia. J. Ecotour. 2017, 16, 112-130. [CrossRef]

2. Alessa, L.; Bennett, S.M.; Kliskey, A.D. Effects of knowledge, personal attribution and perception of ecosystem health on depreciative behaviors in the Intertidal Zone of Pacific Rim National Park and Reserve. J. Environ. Manag. 2003, 68, 207-218. [CrossRef]

3. Miller, D.; Mirrilees, B.; Coghlan, A. Sustainable urban tourism: Understanding and developing visitor pro-environmental behaviours. J. Sustain. Tour. 2015, 23, 26-46. [CrossRef]

4. Tonge, J.; Ryan, M.M.; Moores, S.A.; Beckley, L.E. The effect of place attachment on pro-environmental behavioral intentions of visitors to Coastal Natural Area Tourist Destinations. J. Travel Res. 2015, 54, 730-743. [CrossRef]

5. Kim, M.; Thapa, B. Perceived value and flow experience: Application in a nature-based tourism context. J. Destin. Mark. Manag. 2018, 8, 373-384. [CrossRef]

6. Lee, T.H.; Jan, F.H.; Yang, C.C. Conceptualizing and measuring environmentally responsible behaviors from the perspective of community-based tourists. Tour. Manag. 2013, 36, 454-468. [CrossRef]

7. Lee, T.H.; Jan, F.H. The influence of recreation experience and environmental attitude on the environmentally responsible behavior of community-based tourists in Taiwan. J. Sustain. Tour. 2015, 23, 1063-1094. [CrossRef]

8. Cheng, T.M.; Wu, H.C. How do environmental knowledge, environmental sensitivity, and place attachment affect environmentally responsible behavior? An integrated approach for sustainable island tourism. J. Sustain. Tour. 2015, 23, 557-576. [CrossRef]

9. Thapa, B. The mediation effect of outdoor recreation participation on environmental attitude-behavior correspondence. J. Environ. Educ. 2010, 41, 133-150. [CrossRef]

10. Cheng, T.M.; Wu, H.; Huang, L.M. The influence of place attachment on the relationship between destination attractiveness and environmentally responsible behavior for island tourism in Penghu, Taiwan. J. Sustain. Tour. 2013, 21, 1166-1187. [CrossRef]

11. Fishbein, M.; Manfredo, M.J. A theory of behavior change. Influ. Hum. Behav. 1992, 24, 29-50.

12. Halpenny, E.A. Pro-environmental behaviours and park visitors: The effect of place attachment. J. Environ. Psychol. 2010, 30, 409-421. [CrossRef]

13. Ballantyne, R.; Packer, J.; Sutherland, L.A. Visitors' memories of wildlife tourism: Implications for the design of powerful interpretive experiences. Tour. Manag. 2011, 32, 770-779. [CrossRef]

14. Townsend, C. The Effects of Environmental Education on the Behaviour of SCUBA Divers: A Case Study from the British Virgin Islands. Unpublished Master's Thesis, The University of Greenwich, London, UK, 2000.

15. Amyx, D.A.; DeJong, P.F.; Lin, X.; Chakraborty, G.; Wiener, J.L. Influencers of purchase intentions for ecologically safe products: An exploratory study. In AMA Winter Educators' Conference Proceedings; American Marketing Association: Chicago, IL, USA, 1994; Volume 5, pp. 341-347.

16. Huang, P.S.; Shih, L.H. Effective environmental management through environmental knowledge management. Int. J. Environ. Sci. Technol. 2009, 6, 35-50. [CrossRef]

17. Nicholas, L.; Thapa, B. Visitor perspectives on sustainable tourism development in the Pitons Management Area World Heritage Site, St. Lucia. Environ. Dev. Sustain. 2010, 12, 839-857. [CrossRef]

18. Thapa, B.; Graefe, A.R.; Meyer, L.A. Moderator and mediator effects of scuba diving specialization on marine-based environmental knowledge-behavior contingency. J. Environ. Educ. 2005, 37, 53-67. [CrossRef]

19. Wurzinger, S.; Johansson, M. Environmental concern and knowledge of ecotourism among three groups of Swedish tourists. J. Travel Res. 2006, 45, 217-226. [CrossRef]

20. Liu, S.C.; Lin, H.S. Exploring undergraduate students' mental models of the environment: Are they related to environmental affect and behavior? J. Environ. Educ. 2015, 46, 23-40. [CrossRef]

21. Bricker, K.S.; Kerstetter, D.L. Level of specialization and place attachment: An exploratory study of Whitewater recreationists. Leis. Sci. 2000, 22, 233-257.

22. Fox, D.; Xu, F. Evolutionary and Socio-cultural Influences on Feelings and Attitudes towards Nature: A Cross-cultural Study. Asia Pac. J. Tour. Res. 2017, 22, 187-199. [CrossRef]

23. Korea Expose. Pretty and Polluted: Jeju Overfilling with Tourists. 2017. Available online: https://www. koreaexpose.com/jeju-pretty-polluted-overfilling-tourists/ (accessed on 5 May 2018). 
24. Jeju Special Self-Governing Provincial Tourism Association. 2016. Available online: http:/ /www.visitjeju.or. $\mathrm{kr}$ /web/eng/iota01.do (accessed on 17 June 2018).

25. Kwon, J.; Vogt, C.A. Identifying the role of cognitive, affective, and behavioral components in understanding residents' attitudes toward place marketing. J. Travel Res. 2010, 49, 423-435. [CrossRef]

26. Ryan, C.; Cave, J. Structuring destination image: A qualitative approach. J. Travel Res. 2005, 44, 143-150. [CrossRef]

27. Vogt, C.; Andereck, K. Destination perceptions across a vacation. J. Travel Res. 2003, 41, 348-354. [CrossRef]

28. Mostafa, M.M. A hierarchical analysis of the green consciousness of the Egyptian consumer. Psychol. Mark. 2007, 24, 445-473. [CrossRef]

29. D'Souza, C.; Taghian, M.; Lamb, P. An empirical study on the influence of environmental labels on consumers. Corp. Commun. Int. J. 2006, 11, 162-173. [CrossRef]

30. Bamberg, S.; Möser, G. Twenty years after Hines, Hungerford, and Tomera: A new meta-analysis of psycho-social determinants of pro-environmental behaviour. J. Environ. Psychol. 2007, 27, 14-25. [CrossRef]

31. Conraud-Koellner, E.; Rivas-Tovar, L.A. Study of green behavior with a focus on Mexican individuals. iBusiness 2009, 1, 124-131. [CrossRef]

32. Aertsens, J.; Mondelaers, K.; Verbeke, W.; Buysse, J.; Van Huylenbroeck, G. The influence of subjective and objective knowledge on attitude, motivations and consumption of organic food. Br. Food J. 2011, 113, 1353-1378. [CrossRef]

33. Brucks, M. The effects of product class knowledge on information search behavior. J. Consum. Res. 1985, 12, 1-16. [CrossRef]

34. Boeve-de Pauw, J.; Van Petergem, P. The effect of flemish eco-schools on student environmental knowledge, attitudes, and affect. Int. J. Sci. Educ. 2011, 33, 1513-1538. [CrossRef]

35. Kals, E.; Maes, J. Sustainable development and emotions. In Psychology of Sustainable Development; Springer: Boston, MA, USA, 2002; pp. 97-122.

36. Kollmuss, A.; Agyeman, J. Mind the gap: Why do people act environmentally and what are the barriers to pro-environmental behavior? Environ. Educ. Res. 2002, 8, 239-260. [CrossRef]

37. Chan, R. Environmental attitudes and behavior of consumers in China: Survey findings and implications. J. Int. Consum. Mark. 1999, 11, 25-52. [CrossRef]

38. Chan, R.; Yam, E. Green movement in a newly industrializing area: A survey on the attitudes and behavior of Hong Kong citizens. J. Community Appl. Soc. 1995, 5, 273-284. [CrossRef]

39. Beery, T.; Jönsson, K.I.; Elmberg, J. From environmental connectedness to sustainable futures: Topophilia and human affiliation with nature. Sustainability 2015, 7, 8837-8854. [CrossRef]

40. Louv, R. Last Child in the Woods: Saving Our Children from Nature-Deficit Disorder; Algonquin Books: Chapel Hill, NC, USA, 2008.

41. Junot, A.; Paquet, Y.; Martin-Krumm, C. Passion for outdoor activities and environmental behaviors: A look at emotions related to passionate activities. J. Environ. Psychol. 2017, 53, 177-184. [CrossRef]

42. Davis, J.L.; Green, J.D.; Reed, A. Interdependence with the environment: Commitment, interconnectedness, and environmental behavior. J. Environ. Psychol. 2009, 29, 173-180. [CrossRef]

43. Capaldi, C.A.; Dopko, R.L.; Zelenski, J.M. The relationship between nature connectedness and happiness: A meta-analysis. Front. Psychol. 2014, 5, 1-15. [CrossRef] [PubMed]

44. Wilson, E.O. Biophilia; Harvard University Press: Cambridge, MA, USA, 1984.

45. Nabhan, G.P.; St Antoine, S. The Loss of Floral and Faunal Story: The Extinction of Experience. In The Biophilia Hypothesis; Kellert, R.S., Wilson, E.O., Eds.; Island Press: Washington, DC, USA, 1993; pp. $229-250$.

46. Lee, S.P.; Lin, Y.J. The relationship between environmental attitudes and behavior of ecotourism: A case study of Guandu Natural Park. J. Outdoor Recreat. Stud. 2001, 14, 15-36.

47. Prayag, G.; Hosany, S.; Odeh, K. The role of tourists' emotional experiences and satisfaction in understanding behavioral intention. J. Destin. Mark. Manag. 2013, 2, 118-127. [CrossRef]

48. Schultz, P.W. Empathizing with nature: The effects of perspective taking on concern for environmental issues. J. Soc. Issues 2000, 56, 391-406. [CrossRef]

49. Stern, P.C. Toward a coherent theory of environmentally significant behavior. J. Soc. Issues 2000, 56, 407-424. [CrossRef] 
50. Kellert, S.R. Experiencing Nature: Affective, Cognitive and Evaluative Development in Children. In Children and Nature: Psychological, Sociocultural and Evolutionary Investigation; Kahn, P.H., Jr., Kellert, S.R., Eds.; The MIT Press: Cambridge, MA, USA, 2002; pp. 117-151.

51. Fredrickson, B.L. The role of positive emotions in positive psychology: The broaden-and-build theory of positive emotions. Am. Psychol. 2001, 56, 218-226. [CrossRef] [PubMed]

52. Waugh, C.E.; Fredrickson, B.L. Nice to know you: Positive emotions, self-other overlap, and complex understanding in the formation of a new relationship. J. Posit. Psychol. 2006, 1, 93-106. [CrossRef] [PubMed]

53. Lee, T.H. How recreation involvement, place attachment and conservation commitment affect environmentally responsible behavior. J. Sustain. Tour. 2011, 19, 895-915. [CrossRef]

54. Bissing-Olson, M.J.; Iyer, A.; Fielding, K.S.; Zacher, H. Relationships between daily affect and pro-environmental behavior at work: The moderating role of pro-environmental attitude. J. Organ. Behav. 2013, 34, 156-175. [CrossRef]

55. Griskevicius, V.; Tybur, J.M.; Van den Bergh, B. Going green to be seen: Status, reputation, and conspicuous conservation. J. Pers. Soc. Psychol. 2010, 98, 392-404. [CrossRef] [PubMed]

56. Nisbet, E.K.; Zelenski, J.M.; Murphy, S.A. The nature relatedness scale: Linking individuals' connection with nature to environmental concern and behavior. Environ. Behav. 2009, 41, 715-740. [CrossRef]

57. Kim, M.S.; Thapa, B.; Kim, H. International tourists' perceived sustainability of Jeju Island, South Korea. Sustainability 2018, 10, 73. [CrossRef]

58. Kim, H.; Stepchenkova, S. Understanding destination personality through visitors' experience: A crosscultural perspective. J. Destin. Mark. Manag. 2017, 6, 416-425. [CrossRef]

59. Armstrong, S.J.; Overton, T.S. Estimating nonresponse bias in mail surveys. J. Mark. Res. 1977, 14, $396-402$. [CrossRef]

60. Guthrie, J.P.; Spell, C.S.; Nyamori, R.O. Correlates and consequences of high involvement work practices: The role of competitive strategy. Int. J. Hum. Resour. Man. 2002, 13, 183-197. [CrossRef]

61. Whitehead, J.C.; Groothuis, P.A.; Blomquist, G.C. Testing for non-response and sample selection bias in contingent valuation. Econ. Lett. 1993, 41, 215-220. [CrossRef]

62. Westland, J.C. Lower bounds on sample size in structural equation modeling. Electron. Commer. Res. Appl. 2010, 9, 476-487. [CrossRef]

63. Zsóka, Á.; Szerényi, Z.M.; Széchy, A.; Kocsis, T. Greening due to environmental education? Environmental knowledge, attitudes, consumer behavior and everyday pro-environmental activities of Hungarian high school and university students. J. Clean. Prod. 2013, 48, 126-138. [CrossRef]

64. Polonsky, M.J.; Vocino, A.; Grau, S.L.; Garma, R.; Ferdous, A.S. The Impact of general and carbon-related environmental knowledge on attitudes and behaviour of US consumers. J. Mark. Manag. 2012, 28, 238-263. [CrossRef]

65. Kanchanapibul, M.; Lacka, E.; Wang, X.; Chan, H.K. An empirical investigation of green purchase behaviour among the Young Generation. J. Clean. Prod. 2014, 66, 528-536. [CrossRef]

66. Lee, Y.K.; Choi, J.G.; Kim, M.S.; Ahn, Y.G.; Katz-Gerro, T. Explaining pro-environmental behaviors with environmentally relevant variables: A survey in Korea. Afr. J. Bus. Manag. 2012, 6, 8677-8690.

67. Richer, S.F.; Vallerand, R.J. Construction and validation of the social belonging scale (SAS). Eur. Rev. Appl. Psychol. 1998, 48, 129-138.

68. Chiu, Y.T.H.; Lee, W.I.; Chen, T.H. Environmentally responsible behavior in ecotourism: Antecedents and implications. Tour. Manag. 2014, 40, 321-329. [CrossRef]

69. Nunnally, J.; Bernstenin, I. Psychometric Theory, 3rd ed.; McGraw-Hill: New York, NY, USA, 1994.

70. Anderson, J.C.; Gerbing, D.W. Assumptions and comparative strengths of the two-step approach: Comment on Fornell and Yi. Sociol. Methods Res. 1992, 20, 321-333. [CrossRef]

71. Hair, J.F.; Black, W.C.; Babin, B.J.; Anderson, R.E.; Tatham, R.L. Multivariate Data Analysis; Prentice Hall: Upper Saddle River, NJ, USA, 1998.

72. Bone, P.F.; Sharma, S.; Shimp, T.A. A bootstrap procedure for evaluating goodness-of-fit indices of structural equation and confirmatory factor models. J. Acad. Mark. Sci. 1989, 38, 219-239. [CrossRef]

73. Fornell, C.; Larcker, D.F. Evaluating structural equation models with unobservable variables and measurement error. J. Mark. Res. 1981, 18, 39-50. [CrossRef] 
74. Kim, M.; Stepchenkova, S. Examining the impact of experiential value on emotions, self-connective attachment, and brand loyalty in Korean family restaurants. J. Qual. Assur. Hosp. Tour. 2018, 19, $298-321$. [CrossRef]

75. Bauer, H.H.; Falk, H.; Hammerschmidt, M. eTransQual: A transaction process-based approach for capturing service quality in online shopping. J. Bus. Res. 2006, 59, 866-875. [CrossRef]

76. Podsakoff, P.M.; Organ, D.W. Self-reports in organizational research: Problems and prospects. J. Manag. 1986, 12, 531-544. [CrossRef]

77. Preacher, K.J.; Hayes, A.F. Asymptotic and resampling strategies for assessing and comparing indirect effects in multiple mediator models. Behav. Res. Methods 2008, 40, 879-891. [CrossRef] [PubMed]

78. Lee, Y.K.; Choi, J.; Moon, B.Y.; Babin, B.J. Codes of ethics, corporate philanthropy, and employee responses. Int. J. Hosp. Manag. 2014, 39, 97-106. [CrossRef]

79. Wu, W.C.; Yeh, S.S.; Huan, T.C. Enduring involvement of scuba divers and its relations to their environmental knowledge and environmental behavior. Int. J. Asian Tour. Manag. 2010, 1, 42-53.

80. House, L.; Lusk, J.; Bruce Traill, W.; Moore, M.; Calli, C.; Morrow, B.; Yee, W. Objective and subjective knowledge: Impacts on consumer demand for genetically modified foods in the United States and the European Union. AgBioForum 2004, 7, 113-123.

81. Oviedo-García, M.Á.; Castellanos-Verdugo, M.; Vega-Vázquez, M.; Orgaz-Agüera, F. The mediating roles of the overall perceived value of the ecotourism site and attitudes towards ecotourism in sustainability through the key relationship ecotourism knowledge-ecotourist satisfaction. Int. J. Tour. Res. 2017, 19, $203-213$. [CrossRef]

82. Restall, B.; Conrad, E. A literature review of connectedness to nature and its potential for environmental management. J. Environ. Manag. 2015, 159, 264-278. [CrossRef] [PubMed]

83. Clayton, S. Environmental Identity: Conceptual and Operational Definition. In Identity and the Natural Environment: The Psychological Significance of Nature; Clayton, S., Opotow, S., Eds.; Plenum Press: New York, NY, USA, 2003; pp. 45-65.

84. Baral, N.; Hazen, H.; Thapa, B. Visitor perceptions of World Heritage values at Sagarmatha (Mt. Everest) National Park, Nepal. J. Sustain. Tour. 2017, 25, 1494-1512. [CrossRef]

85. De la Barre, S. Wilderness and cultural tour guides, place identity and sustainable tourism in remote areas. J. Sustain. Tour. 2013, 21, 825-844. [CrossRef]

86. Chan, R.Y.; Lau, L.B. Antecedents of green purchases: A survey in China. J. Consum. Mark. 2000, 17, 338-357. [CrossRef] 